\title{
KOMPETENSI PERATUN UNTUK MEMERIKSA UNSUR PENYALAHGUNAAN WEWENANG
}

\author{
THE COMPETENCE OF ADMINISTRATIVE COURT TO \\ EXAMINE THE ABUSE OF POWER
}

\author{
Aju Putrijanti \\ Fakultas Hukum Universitas Diponegoro \\ Email : ajuputrijanti@live.undip.ac.id

\section{Lapon Tukan Leonard} \\ Fakultas Hukum Universitas Diponegoro \\ Email : leo_tukan@yahoo.com.au
}

\begin{abstract}
The implementation of governance should be based on law and the principles of good governance. The government official and/or government body has an authority based on authority given by the law. The Administrative Court has an authority to investigate the application if there is an abuse of power. This authority is new paradigm after Act No 30 Year 2014 of Governance Administration has been legalized. Previously, to investigate if there is abuse of power, handled by the Court of Corruption, because stated as criminal act. This research use normative juridically approach, principle of law approach and comparative approach. The authority is an important principle in governance, and if there is abuse of power, it should be investigate for the first time by Administrative Court, as competence court. The law enforcement in administrative law, to execute the judge's verdict, is become problems for some years, even the regulation has been amended for two times. The lack of legal obedience is restraint the law enforcement and administrative justice, which should be accpet by the winning party. In future, there should be new regulation which synchronized and harmonized the competence of the court as well as law enforcement.
\end{abstract}

\section{Key words : Administrative Court, Abuse of power, law enforcement.}

\begin{abstract}
Abstrak
Penyelenggaraan pemerintahan harus berdasarkan peraturan perundangan dan Asas Umum Pemerintahan yang Baik (AUPB). Pejabat dan/atau Badan Pemerintah memiliki wewenang sesuai dengan kewenangan yang diberikan. Pemeriksaan ada atau tidaknya unsur penyalahgunaan wewenang menjadi kompetensi Peratun, yan merupakan pengaturan baru setelah UU No 30 tahun 2014 disahkan. Pengaturan ini adalah paradigma baru karena pemeriksaan ada atau tidaknya unsur penyalahgunaan wewenang yang menimbulkan kerugian negara dilaksanakan oleh Peratun, sementara selama ini selalu diaksanakan oleh Pengadilan Tipikor karena merupakan tindak pidana korupsi. Penelitian ini menggunakan metode yuridis normatif, dan pendekatan perundang-undangan, pendekatan asas hukum dan pendekatan komparatif. Wewenang berada di bidang hukum administrasi negara, sehingga ada atau tidaknya unsur penyalahgunaan wewenang, maka harus diperiksa terlebih dahulu di Peratun. Penegakan hukum di bidang hukum administrasi adalah masalah yang selalu timbul, walaupun perundangan tentang Peratun sudah mengalami dua kali amandemen. Ketidaktaatan untuk melaksanakan putusan pengadilan yang telah memperoleh kekuatan hukum tetap adalah menghambat penegakan hukum sehingga belum dapat mewujudkan keadilan administrasi bagi
\end{abstract}


pihak yang menang.Hasil penelitian menunjukkan bahwa perlu dibuat perundangan baru yang secara tegas menyebutkan kompetensi Peratun serta melakukan sinkronisasi dengan perundangan lain di bidang hukum pidana, sehingga penegakan hukum bidang hukum administrasi negara dapat terlaksana.

Kata kunci: Peradilan Tata Usaha Negara, Penyalahgunaan Wewenang, Penegakan Hukum

\section{PENDAHULUAN}

Sebagai negara hukum, segala tindakan Pemerintah harus berdasarkan hukum, ada pembatasan kekuasaan negara, perlindungan terhadap hak asasi manusia, hal ini penting agar pemerintah tidak bertindak sewenang-wenang atau agar tidak terjadi penyalahgunaan wewenang yang dapat menimbulkan kerugian. Asas legalitas memiliki peran penting dalam penyelenggaraan pemerintahan.

Peradilan Tata Usaha Negara atau untuk selanjutnya akan disebut Peratun adalah lembaga peradilan yang memiliki kewenangan untuk memeriksa, memutus dan menyelesaikan sengketa tata usaha negara. Peran Peratun semakin penting untuk melaksanakan fungsi peradilan yang dilaksanakan bersama dengan fungsi pengawasan. Pengawasan terhadap jalannya pemerintahan perlu untuk dilakukan dan ditingkatkan, agar dapat mewujudkan tata kelola pemerintahan yang baik (good governance). Fungsi pengawasan oleh Peratun adalah penting untuk menjamin dilindungi serta terpenuhinya hak sebagai warga negara, dan penegakan hukum administrasi negara dalam kerangka negara hukum. Penegakan hukum administrasi di beberapa bidang, nampaknya kurang berjalan sesuai dengan keadaan yang ada.

UU No 30 Tahun 2014 tentang Administrasi Pemerintahan (untuk selanjutnya dalam artikel ini disebut UU AP) mengatur mulai pemberian wewenang kepada pejabat dan/ atau badan tata usaha negara hingga larangan melakukan penyalahgunaan wewenang, pemberian sanksi administratif dan jenis sanksi yang dapat diberikan. Pasal 21 UU AP menjadi dasar hukum bagi Peratun untuk memeriksa penilaian unsur penyalahgunaan wewenang yang sebenarnya adalah hal baru dalam kompetensi Peratun. Untuk dapat melaksanakan isi Pasal 21 UU AP, Mahkamah Agung mengeluarkan Peraturan Mahkamah Agung Republik Indonesia No 4 Tahun 2015 tentang Pedoman Beracara dalam Penilaian Unsur Penyalahgunaan Wewenang. Kewenangan Peratun untuk memeriksa, memutus dan menilai unsur penyalahgunaan wewenang, menarik untuk dikaji lebih luas, karena sebelum UU AP disahkan, pemeriksaan penyalahgunaan wewenang yang menimbulkan kerugian negara diperiksa oleh Pengadilan Tipikor.

Dikemukakan oleh Philipus M. Hadjon, beberapa hal penting mengenai Peratun dalam konteks UU AP, apabila dibandingkan dengan Algemene wet Bestuursrecht ( AwB) nampak perbedaan yang jelas, yaitu AwB bertitik tolak dari hukum administrasi negara, sedangkan UU AP bertitik tolak dari administrasi pemerintahan. Pendapat yang dikemukakan terkait Pasal 21 UU AP yaitu dalam konteks apa seorang pejabat TUN mengajukan permohonan berdasar Pasal 21 ayat (3), serta apakah putusan pengadilan bersifat mengikat dalam hal ada dakwaan terkait Pasal 3 UU Tipikor? ${ }^{1}$

Maftuh Effendi mengemukakan bahwa kompetensi Peratun berdasar UU No 5 Tahun 1986 tentang Peratun jo UU No 51 Tahun 2009 (untuk selanjutnya disebut UU Peratun) mengalami beberapa pembatasan, sehingga menjadikan eksistensi Peratun bersifat khusus seperti Wet Algemene Rechtspraak Overhieds beschikkingen (AROB) Belanda dan

${ }^{1}$ Philipus M. Hadjon, "Peradilan Tata Usaha Negara Dalam Konteks UU No 30 Tahun 2014 Tentang Adminisitrasi Pemerintahan," http://www.jurnalhukumdanperadilan.org/index.php/jurnalhukumperadilan. Jurnal Hukum Dan Peradilan 4, no. 1 (2015): 51-63., diakses tanggal 26 November 2018 
bukan bersifat umum, bahkan bersifat super khusus, karena Keputusan TUN dalam UU Peratun lebih sempit daripada beschikking dalam AwB di Belanda. Sehingga sengketa menyangkut perbuatan hukum pemerintah lainnya menjadi kompetensi peradilan umum, yang menimbulkan permasalahan hukum dalam penanganannya ${ }^{2}$.

Tri Cahya Indra Permana menyebutkan, bahwa konsep peyalahgunaan wewenang adalah konsep dalam hukum administrasi negara yang diabsorpsi ke dalam hukum pidana, sehingga lebih tepat jika pemeriksaan ada atau tidaknya unsur penyalahgunaan wewenang dilakukan oleh Peratun ${ }^{3}$.

Terkait dengan implikasi putusan Hakim Peratun yang menyatakan ada unsur penyalahgunaan wewenang, selama ada terbukti ada niat jahat maka dapat dilanjutkan ke peradilan pidana. Namun, jika tidak ada unsur penyalahgunaan wewenang, maka tidak dapat dilanjutkan ke peradilan pidana, karena tidak terpenuhinya bestand delict sesuai Pasal 3 UU Tipikor. ${ }^{4}$

Adanya conflict of normantaraPasal3UU Nomor 31 Tahun 1999 tentang Pemberantasan Tindak Pidana Korupsi jo Undang-undang Nomor 20 Tahun 2001 tentang Perubahan Atas Undang-undang Nomor 30 Tahun 1999 tentang Pemberantasan Tindak Pidana Korupsi ( untuk selanjutnya disebut UU Tipikor) dengan Pasal 21 UU AP berkaitan dengan kompetensi absolut, hal tersebut timbul karena belum ada kesatuan perspektif dalam melihat UU AP terhadap penilaian penyalahgunaan wewenang, yang berakibat pada ketidakpastian mekanisme penanganan masalah tersebut. ${ }^{5}$.

Dari data awal ditemukan ada permohonan ada atau tidaknya unsur penyalahgunaan wewenang diperiksa dan diputus oleh Peratun dengan pertimbangan bahwa terhadap pemohon telah menjalani pidana atau berstatus sebagai tersangka dalam pemeriksaan tindak pidana korupsi, sehingga permohonan ditolak. Di satu sisi ada pula permohonan penilaian ada atau tidaknya unsur penyalahgunaan wewenang yang dikabulkan dengan obyek permohonan yang berbeda pada kasus tersebut. Permohonan ada atau tidaknya unsur penyalahgunaan wewenang tidak banyak diajukan ke Peratun, yang dapat dilihat dari Sistem Informasi Penulusuran Perkara (SIPP) di Peratun, meskipun hal tersebut sudah ditegaskan dalam Pasal 21 UU AP.

Beberapa kajian ilmiah dan penelitian di atas membahas masalah kompetensi Peratun, yang terus berkembang sehingga hal ini menarik peneliti untuk mengetahui bagaimana kompetensi Peratun dalam hal pemeriksaan permohonan penyalahgunaan wewenang serta bagaimana penegakan hukum di bidang hukum administrasi negara? Dari hasil penelitian di atas, peneliti berusaha untuk melengkapi dengan melakukan kajian komparasi di beberapa negara yang memiliki peradilan administrasi, baik yang masuk dalam Common Law sistem maupun Civil Law sistem, terhadap kompetensi Peratun untuk menilai unsur penyalahgunaan wewenang, serta untuk dapat tercapainya keadilan administrasi (administration of justice). Penegakan hukum di

\footnotetext{
${ }^{2}$ Maftuh Effendi, "Peradilan Tata Usaha Negara Indonesia Suatu Pemikiran Ke Arah Perluasan Kompetensi Pasca Amandemen Kedua Undang-Undang Peradilan Tata Usaha Negara," http://www.jurnalhukumdanperadilan.org/ index.php/jurnalhukumperadilan. Jurnal Hukum Dan Peradilan 3, no. 1 (2014): 25-35.diakses tanggal 8 Desember 2018

${ }^{3}$ Tri Cahya Indra Permana, "Peradilan Tata Usaha Negara Pasca Undang-Undang Administrasi Pemerintahan Ditinjau Dari Segi Access To Justice ( The Administrative Court After Government Administration Acts In Terms of Access To Justice), http://www.jurnalhukumdanperadilan.org/index.php/jurnalhukumperadilan/article/view/52/63" Jurnal Hukum Dan Peradilan 4, no. 3 (2015): 419-42.diakses pada tanggal 25 Novermber 2018

${ }^{4}$ Firna Novi Anggoro, "Pengujian Unsur Penyalahgunaan Wewenang Terhadap Keputusan Dan/Atau Tindakan Pejabat Pemerintahan Oleh PTUN," http://jurnal.fh.unila.ac.id/index.php/fiat Fiat Justisia 10, no. 4 (2016): 629-52. diakses pada tanggal 9 Desember 2018.

${ }^{5}$ Mohammad Sahlan, "Kewenangan Peradilan Tipikor Pasca Berlakunya UU No 30 Tahun 2014 Tentang Administrasi Pemerintahan," https://arenahukum.ub.ac.id Arena Hukum 9, no. 2 (2016): 166-69.diakses pada tanggal 9 Desember 2018
} 
bidang hukum administrasi negara tidak hanya melaksanakan putusan pengadilan yang telah memperoleh kekuatan hukum tetap, tetapi juga meliputi kepatuhan warga negara termasuk pejabat pemerintah untuk melaksanakan perundang-undangan terkait. Larangan menyalahgunakan wewenang yang secara tegas sudah diatur dalam undangundang, harus dipatuhi agar tidak menimbulkan permasalahan hukum dan dapat mewujdukan keadilan administrasi.

Metode penelitian yang digunakan adalah yuridis normatif, serta menggunakan bahan hukum primer dan bahan hukum sekunder, dan menggunakan pendekatan asas, pendekatan komparasi dan pendekatan undang-undang. Bahan hukum primer bersifat otoritatif artinya mempunyai otoritas yang terdiri atas peraturan perundangan, putusan Pengadilan yang berkekuatan hukum tetap Bahan hukum sekunder yang digunakan adalah jurnal, hasil penelitian dan buku. ${ }^{6}$

Penyelenggaraan pemerintahan harus ada pengawasan yang bersifat ekstern maupun intern, terutama dalam hal penyalahgunaan wewenang yang merupakan pelayanan publik, sementara penggunaan wewenang yang tidak sesuai dengan dasar diberikannnya wewenang memiilki potensi timbulnya tindak pidana korupsi, sehingga terkait dengan pengawasan maka hukum adminisitrasi memiliki peran penting dalam upaya pemberantasan tindak pidana korupsi ${ }^{7}$.

Hukum adminisitrasi negara sangat penting untuk mengatur pemerintahan dan dimungkinkan melintas batas serta bersinggunggan dengan bidang hukum lain, misal hukum pidana atau hukum perdata, apabila perbuatan pemerintah melampaui wewenang yang dapat menimbulkan penyalahgunaan wewenang dan menjadi tindak pidana korupsi ${ }^{8}$. Wewenang yang dimiliki pemerintah secara tegas berada di ranah hukum administrasi negara, karena terkait dengan kewenangan sebagai kekuasaan badan dan/atau pejabat pemerintah untuk menyelenggarakan pemerintahan dalam ranah hukum publik.

Korupsi timbul karena ada penyalahgunaan wewenang yang dilakukan oleh Pejabat dan/ atau Badan Pemerintah, bertitik tolak dari hal tersebut, maka yang harus diutamakan adalah pemeriksaan dari sisi hukum administrasi negara. Hal tersebut juga dapat dilihat sebagai upaya penegakan hukum bidang hukum administrasi negara, demi terciptanya pemerintahan yang bersih bebas dari korupsi, kolusi dan nepotisme.

\section{PEMBAHASAN}

\section{Peradilan Tata Usaha Negara}

Arti penting lembaga peradilan dalam pemerintahan yaitu pertama, sebagai upaya perlindungan hukum warga negara dari tindakan hukum pemerintah, kedua sebagai pengawasan terhadap penyelenggaraan pemerintahan atau sebagai sarana kontrol dari masyarakat, ketiga sebagai unsur yudikatif dalam negara hukum untuk menjamin supremasi hukum. Pengawasan oleh Peratun merupakan pengawasan dalam perspektif hukum administrasi negara, yang bertujuan untuk menilai apakah pelaksanaan tugas

\footnotetext{
${ }^{6}$ Ishaq, 2016, "Penelitian Hukum Dengan Menggunakan Metode Penelitian Sosial," in Metode Penelitian Hukum Dan Penulisan Skripsi, Tesis Serta Disertasi, Alfabeta, Bandung,hlm 68-70.

${ }^{7}$ Philipus M. Hadjon, dkk, 2011, "Maladministrasi Dan Peran Pengawasan Dalam Pelayanan Publik," in Hukum Administrasi Dan Tindak Pidana Korupsi”, Gadjah Mada University Press, Yogyakarta, hlm 39-41.

${ }^{8}$ Bagir Manan, 2009."Perlindungan Hukum Terhadap Pejabat Publik Daerah," in Menegakkan Hukum Suatu Pencarian, Asosiasi Advokat Indonesia, Jakarta, hlm 305-21.
} 
dan pekerjaan telah dilaksanakan sesuai dengan norma hukum yang berlaku dan apakah pencapaian tujuan tidak melanggar norma hukum yang berlaku ${ }^{9}$.

Penjelasan perlu dibentuknya Peratun untuk mewujudkan kehidupan bernegara dan bangsa, menjamin kesamaan kedudukan warga negara di depan hukum dan pemerintahan yang harus disesuaikan dengan pandangan hidup bangsa yaitu Pancasila, sehingga tercapai keserasian, keselarasan dan kekseimbangan antara kepentingan perseorangan dengan kepentingan umum serta tujuan lainnya, hal inilah yang menjadikan Peratun di Indonesia memiliki karakteristik khusus, yang menurut Oemar Seno Adji,negara hukum Indonesia disebut sebagai negara hukum Pancasila ${ }^{10}$.

Pengawasan oleh lembaga peratun memiliki sifat yang berbeda dengan pengawasan oleh instansi terkait atau yang secara struktural berada di atas pejabat dan/atau badan pemerintahan yang diperiksa. Dikemukakan oleh Paulus Effendi Lotulung, perbedaan yang dimaksud adalah, bahwa pengawasan bersifat eksternal karena dilakukan oleh lembaga yang berada di luar instansi terkait, pengujian asas legalitas terhadap keputusan tata usaha negara, dilakukan setelah terjadinya tindakan hukum yang dikontrol atau bersifat a-posteriori. ${ }^{11}$

Asas legalitas dalam penyelenggaraan pemerintahan yang menjadi dasar bagi lembaga peradilan untuk melakukan pengawasan yaitu dengan menguji berdasar peraturan perundang-undangan yang berlaku. Pengujian terhadap keputusan tata usaha negara dilakukan meliputi pertama, prosedur dikeluarkannya obyek sengketa, kedua, substansi dari obyek sengketa, ketiga, wewenang yang dimiliki oleh Pejabat dan/atau Badan Tata Usaha Negara. Selain berdasar peraturan perundangan, pengujian juga didasarkan pada Asas-asas Umum Pemerintahan yang Baik ( selanjutnya disebut AUPB) di Pasal 7 UU AP serta perundangan lain yang mengatur mengenai AUPB.

Pengujian berdasar peraturan perundangan dan AUPB banyak digunakan di beberapa negara, hal ini karena AUPB berasal dari praktek pemerintahan yang bersifat universal dan dinamis. Dengan digunakannya AUPB sebagai batu uji terhadap keputusan TUN yang disengketakan, diharapkan dapat terwujud keadilan sebagaimana diharapkan oleh pihak yang bersengketa.

UU Peratun adalah hukum formil di bidang hukum administrasi negara yang mengatur kompetensi absolut, prosedur beracara, putusan, dan pelaksanaan putusan pengadilan yang telah memperoleh kekuatan hukum tetap. Kompetensi absolut Peratun menurut Thorbecke menekankan pada pokok sengketa (fundamentum petendi) yang terletak di hukum publik, maka yang berwenang memutus adalah Hakim administrasi, pendapat lain dikemukakan oleh Buys bahwa yang menentukan adalah pokok dalam perselisihan (objectum litis) ${ }^{12}$. UU No 5 Tahun 1986 tentang Peratun menyebutkan pembatasan kompetensi absolut yaitu Pasal 2 mengenai keputusan tata usaha negara yang tidak termasuk pengertian keputusan tata usaha negara yang bisa digugat di Peratun, Pasal 49 tentang pembatasan kewenangan Peratun untuk memeriksa, memutus dan menyelesaikan keputusan TUN yang dikeluarkan pada kondisi tertentu.

Sehubungan dengan kompetensi absolut, mengenai Pasal 49 UU No 5 Tahun 1986 tentang Peratun, Indroharto menyebutkan hal tersebut mempersempit ruang lingkup

\footnotetext{
${ }^{9}$ Ridwan, 2009, Tiga Dimensi Hukum Administrasi Dan Peradilan Administrasi, FH UII Press, Yogyakarta, hlm 127.

${ }^{10}$ Paulus Effendi Lotulung, 2013, "Peratun Dalam Kaitannya Dengan Rechtsstaat Republik Indonesia," in Hukum Tata Usaha Negara Dan Pemerintahan, 1st ed. Salemba Humanika, Jakarta, hlm 7-13.

${ }^{11}$ Paulus Effendi Lotulung, op.cit, hlm 14.

${ }^{12}$ Nomensen Sinamo, 2016, "Kompetensi Peradilan Tata Usaha Negara," in Hukum Acara Peradilan Tata Usaha Negara, Jala Permata Aksara, Jakarta, hlm 45.
} 
kompetensi Pengadilan, karena meskipun memenuhi kriteria sebagai keputusan tata usaha negara yang dapat digugat, namun pembatasan tertentu menyebabkan hal tersebut tidak dapat diajukan sebagai obyek gugatan. ${ }^{13}$. Mengenai kompetensi absolut ada 2 (dua) pendapat, yaitu pandangan dalam arti luas yang menyebutkan bahwa kompetensi absolut meliputi segala tindakan hukum pemerintah baik tertulis maupun tidak tertulis, sengketa yang bersifat ekstern maupun intern. Pandangan dalam arti sempit, menyatakan kompetensi absolut terbatas pada keputusan tata usaha negara secara tertulis dan bersifat ekstern saja ${ }^{14}$. Pandangan dalam arti luas yang menyebutkan kompetensi absolut meliputi segala tindakan hukum pemerintah, pada kondisi saat ini perlu untuk dipertimbangkan lebih lanjut. Adapun alasan perlunya mengkaji kompetensi absolut dalam arti luas, dengan pertimbangan hukum yang didasarkan pada isi Pasal 21, 53 dan 87 UU AP.

Secara komparatif mengenai kompetensi Peratun, di Inggris, yang masuk dalam sistem Common Law dikenal Administrative Tribunal yang merupakan bagian dari Queen's Bench Division serta memiliki batasan tertentu yaitu tidak hanya penanganan masalah administrasi tetapi juga kriminal, serta bukan bagian dari sistem peradilan yang ada. Spanyol yang masuk dalam sistem civil law tradition memiliki Peradilan Administrasi dengan kompetensi untuk menyelesaikan sengketa administrasi dan keberadaannya berjenjang. Belgia tidak memiliki Peradilan Administrasi di tingkat pertama, namun The Constitutional Court sebagai Superior Administrative Court yang mengawasi tindakan pemerintah di bidang, namun tidak dijelaskan hal apa saja yang termasuk diawasi. Peradilan Administrasi di Ukraina dibentuk tahun 2002 dengan kompetensi yaitu sengketa antara individu atau badan hukum dengan pemerintah dalam hal kegagalan terhadap keputusan atau tindakan oleh pemerintah, antar lembaga pemerintah mengenai kewenangan, dengan pengecualian dalam hal pengenaan denda terhadap kejahatan administrasi ( provision on imposing penalty of administrative offences) ${ }^{15}$.

Michael Asimow mengemukakan, ada 5 (lima) model dan dalam prakteknya tidak ada suatu sistem yang bersifat superior namun setiap sistem dapat di desain ulang dan pilihan untuk menggabungkan model sudah tentu berdasarkan budaya hukum dan kompromi politik setiap negara. Lima model yang dikemukakan yaitu pertama bersifat adversarial hearing, combined function and limited judicial review, kedua inquisitorial hearing, combined function, limited judicial review, ketiga tribunal system, keempat open judicial review, kelima specialized court yang digunakan di Perancis, Jerman, Asia, Amerika Latin dan beberapa negara Eropa. ${ }^{16}$. Model yang kelima ini yang digunakan di Peratun, dengan ciri lembaga peradilan yang terpisah dari peradilan umum dan hanya memutus sengketa administrasi. Secara historis karena ada pengaruh sistem hukum Administrasi Negara dari Belanda, sementara ada kemiripan antara hukum administrasi negara Belanda, Perancis. Pada saat upaya Pemerintah melakukan pembentukan

\footnotetext{
${ }^{13}$ Indroharto, 2000, Usaha Memahami Undang-Undang Tentang Peradilan Tata Usaha Negara Buku I Beberapa Pengertian Dasar Hukum Tata Usaha Negara, Sinar Pustaka Harapan, Jakarta, hlm. 131

${ }_{14}$ Priyatmanto Abdoellah, 2016, Revitalisasi Kewenangan PTUN Gagasan Perluasan Kompetensi Peradilan Tata Usaha Negara, Cahaya Atma Pustaka, Yogyakarta, hlm 45-47.

${ }^{15}$ Ziya Bekir BUĞUÇAM, "Common Principles of Judicial Review of Administration in Europe: A Comparative Study of France, The UK, The ECHR and the EU," http://www.taa.gov.tr/indir/common-principles-of-judicial-review-of-administration-in-europe-a-comparative-study-of-france-the-uk-the-echr-and-the-eu-bWFrYWxlfDBkYTlmLWUwNmQ4LTg2NGM5LTUwOTE5LnBkZnw1NTgL., Law \& Justice Review, December, Year III, No 5, 2012, diakses pada tanggal 30 November 2018.

${ }^{16}$ Michael Asimow, "Five Models OfAdministrative Adjudication," The American Journal of Comparative Law 63, https://academic.oup.com/ajcl, Vol. 63, Issue July 2018, pg 3-32. Diakses pada tanggal 14 November 2018.
} 
lembaga pengadilan Tata Usah Negara, dilakukan studi komparasi ke Perancis, Belanda, sehingga dapat dipahami apabila model specialized court yang digunakan di Indonesia.

\section{Penyalahgunaan Wewenang}

\section{a. Perspektif Hukum Administrasi}

Konsep penyalahgunaan wewenang adalah konsep yang berasal dari Counseil d'EtatPerancis, yang mengandung maknabahwa pemerintah menggunakan wewenang sesuai dengan tujuan dalam undang-undang dan melakukan tindakan sesuai tujuan. Dilengkapi dengan pendapat Schrijvers dan Smeets bahwa organ pemerintah hanya boleh menggunakan wewenang yang diberikan, untuk tujuan yang telah ditetapkan, serta larangan penggunaan wewenang untuk tujuan lain dari yang sudah ditentukan oleh pembuat undang-undang ${ }^{17}$

Konsep penyalahgunaan wewenang di Inggris disebut abuse of power, sama dengan diPerancis yaitu detournement depouvoir yang memilikiartipenyalahgunaan wewenang oleh pejabat dengan menyimpang dari ketentuan undang-undang yang berlaku. Penyalahgunaan wewenang dapat terjadi karena : ${ }^{18}$

1. Menggunakan wewenang untuk kepentingan pribadi atau tujuan politik.

2. Menggunakan wewenang bertentangan dengan undang-undang yang memuat dasar hukum wewenang yang diberikan.

3. Menjalankan wewenang untuk tujuan lain dari yang dikehendaki oleh undangundang dengan wewenang tersebut.

Pengertian penyalahgunaan wewenang ada 3 (tiga) bentuk, sebagaimana dikemukakan oleh Prof. Jean Rivero dan Prof Waline, sebagai berikut : ${ }^{19}$

1. Penyalahgunaan kewenangan untuk melakukan tindakan-tindakan yang bertentangan dengan kepentingan umum atau untuk menguntungkan kepentingan pribadi, kelompok atau golongan

2. Penyalahgunaan kewenangan dalam arti bahwa tindakan pejabat tersebut adalah benar ditujukan untuk kepentingan umum, tetapi menyimpang dari tujuan apa kewenangan itu diberikan oleh undang-undang atau peraturan lain

3. Penyalahgunaan kewenangan dalam arti menyalahgunakan prosedur yang seharusnyadipergunakanuntukmencapaitujuantersebut, tetapitelahmenggunakan prosedur lain agar terlaksana.

AUPB tercantum pada Pasal 10 UU AP yaitu: kepastian hukum, kemanfaatan, ketidakberpihakan, kecermatan, tidak menyalahgunakan kewenangan, keterbukaan, kepentingan umum dan pelayanan yang baik. adalah asas yang mewajibkan setiap badan dan/atau Pejabat Pemerintahan tidak menggunakan kewenangannya untuk kepentingan pribadi atau kepentingan yang lain dan tidak sesuai dengan tujuan pemberian kewenangan tersebut, tidak melampaui, tidak menyalahgunakan, dan/ atau tidak mencampuradukkan kewenangan.

\section{b. Dalam perspektif Hukum Pidana}

\footnotetext{
${ }^{17}$ Ridwan, 2016, Persinggungan Antar Bidadng Hukum Dalam Perkara Korups, FH UII Press, Yogyakarta, hlm. 12-13.

${ }^{18}$ Philipus M. Hadjon et. al, 2011, Hukum Administrasi Dan Tindak Pidana Korupsi, Gadjah Mada University Press, Yogyakarta, hlm 44.

${ }^{19}$ Budi Suhariyanto, 2018, "PENYALAHGUNAAN DISKRESI ANTARA PENGADILAN TUN DAN PENGADILAN TIPIKOR (INTERCEPTION OF JUSTICE AUTHORITY OF DISCRETION ABUSE BETWEEN ADMINISTRATION COURT AND CORRUPTION COURTS)," http://www.jurnalhukumdanperadilan.org/index.php/jurnalhukumperadilan/article/view/52/63 Jurnal Hukum Dan Peradilan 7, no. 2, hlm 213-36. di akses pada tanggal 15 Novermber 2018.
} 
Terkait perkembangan pengaturan norma penyalahgunaan wewenang dalam pemberantasan tindak pidana korupsi yang secara historis dimulai pada Peraturan Penguasa Militier No.PRT/PM/06/1957 tanggal 9 April 1957, Peraturan Penguasa Perang Pusat Angkatan Darat No. PRT/Peperpu/013/1958 tanggal 16 April 1958, UU No24/Prp/1960 tangga19Juni 1960 tentang Pengusutan, Penuntutan dan Pemeriksaan Tindak Pidana Korupsi, UU No 3 Tahun 1971 tentang Pemberantasan Tindak Pidana Korupsi, UU No 31 Tahun 1999 tentang Pemberantasan Tindak Pidana Korupsi, Pasal 52 KUHP, Pasal 55 ayat (1) ke-2 KUHP. Selain itu dapat pula dibaca yurisprudensi putusan Mahkamah Agung RI No 88 K/Kr/1969 tanggal 3 November dan putusan Mahkamah Agung RI No 77 K/Kr/1973 tanggal 19 November 1974 didalamnya secara implisit mengandung konsep penyalahgunaan wewenang. Putusan Mahkamah Agung RI No 1340 K/Pid/ 1992 tanggal 17 Februari 1992 secara expressis verbis menunjuk dan mengambil alih pengertian penyalahgunaan wewenang sebagaimana diatur dalam Pasal 53 ayat (2) UU No 5 Tahun 1986 tentang Peratun. Mahkamah Agung RI merujuk secara langsung ketentuan Pasal 53 ayat (2) huruf b UU No 5 Tahun 1986 dalam Putusan MA No 977K/Pid/2004, Putusan No 979 K/Pid/2004 dan Putusan 742 K/ $\mathrm{Pid} / 2007 .{ }^{20}$

Dikutip dari Disiplin Manao, sebagaimana dikemukakan oleh Adam Chazawi, perbuatan menyalahgunakan wewenang terjadi jika seseorang yang memiliki kewenangan berdasarkan ketentuan yang dimilikinya digunakan secara menyimpang bertentangan dengan maksud dan tujuan diberikannya wewenang tersebut ${ }^{21}$.

\section{c. Kompetensi Peratun dalam memeriksa permohonan ada atau tidaknya unsur pe- nyalahgunaan wewenang.}

Konsep negara hukum ada yang menggunakan istilah Rule of Law yang banyak digunakan di negara yang menggunakan sistem hukum Common Law, dan Rechtsstaat digunakan di negara yang menggunakan sistem hukum Civil Law. Selain dua sistem hukum tersebut, ada pula negara yang menggunakan sistem hukum Sosialis, Africa Sahara, Islam, Amerika Latin yang masing-masing tentunya berbeda dalam filosofi, budaya serta memiliki unsur khusus dalam negara hukum sehingga menciptakan sistem hukum yang berbeda.

Dari sistem hukum Civil Law, F.J. Stahl menyebutkan bahwa salah satu unsur negara hukum adalah adanya peradilan administrasi yang menyelesaikan sengketajika terjadipelanggaran hak asasi warga negara. Sementara dari sistem hukum Common Law, unsur negara hukum yang dikemukakan oleh A.V. Dicey, tidak mencantumkan adanya peradilan administrasi. Mengikuti sistem hukum Civil Law, Indonesia membentuk PeratunsebagailembagaperadilanyangberadadibawahMahkamahAgungdanmemiliki kompetensi absolut, sehingga memiliki kekhususan peradilan (specialized court).

Meskipun demikian, ada unsur yang bersifat umum sebagaimana dikemukakan oleh Ricardo Gosalbo-Bono , "...any universal definition of the rule of law will have to incorporate, at least with three (3) principles are: (1) principles that power may not be exercise arbitrarily, which requires a rejection of the rule by man and requires that law should be prospective, accessible, and clear (2) the principles of the supremacy of the law, which distinguishes the rule oflaw from the rulebylaw and implies acceptance the principles

${ }^{20}$ Disiplin F.Manao, 2017, Penyalahgunaan Wewenang Pada Tindak Pidana Korupsi Dalam Perspektif Hukum Administrasi Negara, Kreasi Sahabat Bersama, Bandung, hlm 79 -80.

${ }_{21}$ Disiplin F.Manao, 2018, "Penyelesaian Penyalahgunaan Wewenang Oleh Aparatur Pemerintah Dari Segi Hukum Administrasi Dihubungkan Dengan Tindak Pidana Korupsi," , http://ejournal sthb.ac.id/index.php/jwy. Vol.2, No 1, Wawasan Yuridika, hlm 1-22., diakses pada tanggal 2 Desember 2018. 
of separation of powers or the idea that laws applies to all, including the sovereign, with an independent institution, such as judiciary, to apply the law to spesific cases, (3) the principles that law must apply to all person equally, offering equal protection without any discrimination or the idea that the law should be of general application and should be capable of being obeyed ${ }^{22}$.

Ketiga prinsip umum di atas, sudah tercakup dalam UU No 48 Tahun 2009 tentang Kekuasaan Kehakiman, yang menegaskan bahwa kekuasaan kehakiman adalah kekuasaanyangmerdekauntukmenyelenggarakan peradilangunamenegakkanhukum dan keadilan berdasarkan Pancasila dan UUD 1945, larangan campur tangan dari pihak manapun dalam urusan peradilan, kecuali dalam hal yang diatur berdasar UUD 1945, Hakim dan Hakim Konstitusi wajib menjaga kemandirian peradilan, pengadilan mengadili menurut hukum dengan tidak membeda-bedakan, sidang pengadilan adalah terbuka untuk umum, kecuali undang-undang menentukan lain.

Dalam negara hukum, segala tindakan pemerintah harus berdasarkan perundangundangan yang berlaku, hal ini adalah mutlak dan penting, karena untuk memberi perlindungan hukum terhadap hak warga negara, mencegah kekuasaan yang bersifat absolut, yang sesungguhnya merupakan perwujudan asas legalitas.

UU AP mengatur secara tegas kewenangan Pemerintahan yaitu dalam Pasal 8 bahwa penyelenggaraan pemerintahan harus berdasarkan kewenangan yang dimiliki, wewenang yang dimiliki wajib berdasarkan peraturan perundangan yang berlaku dan AUPB, serta larangan melakukan penyalahgunaan wewenang.

Asas legalitas memegang peran penting dalam pemerintahan yaitu sebagai dasar hukum pemberian kewenangan dan wewenang kepada Pejabat dan atau Badan Tata Usaha Negara. Setiap tindakan pemerintah harus berdasarkan hukum dan merupakan salah satu bentuk wujud perlindungan terhadap hak asasi manusia..

Asas spesialisasi, dikemukakan oleh Marieete Kobussen, yang secara substansial mengandung makna bahwa setiap kewenangan memiliki tujuan tertentu, apabila ada penyimpangan, makatimbulpenyalahgunaanwewenangataudetournementdepouvoir. ${ }^{23}$. Asas spesialisasi ini yang menjadi dasar pemerintah untuk melaksanakan wewenang yang dimiliki untuk mencapai tujuan negara.

Hubungan antara asas legalitas dan asas spesialisasi dapat dijelaskan bahwa keduanyaberdampingan yaitu asas legalitas memberilandasan hukumbagi pemerintah untuk menjalankan wewenangnya guna mencapai tujian yang diberikan melalui asas spesialisasi, sehingga apabila penggunaan wewenang menyimpang dari tujuan, maka terjadi penyalahgunaan wewenang.

Menurut H.D. Stout, kewenangan yang diberikan berdasarkan asas legalitas yang menimbulkan wewenang bagi pemerintah, sehingga merupakan konsep inti dalam hukum administrasi negara dan hukum tata negara, diperkuat pendapat yang dikemukakan oleh F.A.M. Stroink dan J.G. Steenbeek. ${ }^{24}$. F.A.M.Stroink membagi kewenangan berdasarkan hukum publik adalah kemampuan yuridis dari badan, selain itu dapat bersifat ketatanegaraan serta sebagai wewenang yang diberikan dan dilaksanakan oleh lembaga negara, dan bersifat administrasi yang dilaksanakan oleh adminisitrasi pemerintahan. Wewenang pemerintah adalah hak dan kewajiban yang

${ }^{22}$ Ricardo Gosalbo-bono, 2010, "The Significance of the Rule of Law and It's Implications For The European Union And The United States," University of Pittsburgh Law Review 72, no. 2, https://awreview.law.pitt.edu/, hlm 229-360.diakses pada 5 November 2018.

${ }^{23}$ Ali Abdullah, 2017, Teori Dan Praktik Hukum Acara Peradilan Tata Usaha Negara, Kencana, Jakarta, hlm.9.

${ }^{24}$ Ridwan, 2003, "Kedudukan, Kewenanga, Dan Tindakan Hukum Pemerintah," dalam Hukum Administrasi Negara, UII Press, Yogyakarta,hlm 65-79. 
diberikan kepada organ pemerintahan untuk melakukan tindakan hukum serta dapat menimbulkan akibat hukum ${ }^{25}$.

Secara tegas dalam Pasal 8 UU AP disebutkan bahwa badan dan/atau pejabat pemerintah dalam menjalankan wewenangnya harus berdasarkan asas legalitas dan AUPB. Adalah kewajiban bagi badan dan/atau pejabat pemerintah untuk mencantumkan atau menunjukkan ketentuan peraturan perundangan yang menjadi dasar kewenangannya dalam menetapkan dan/atau melakukan keputusan dan/atau tindakan.

Penyelenggaraan pemerintahan berdasarkan asas legalitas yang memberi kewenangan kepada pejabat dan/atau badan pemerintahan untuk bertindak sesuai dengan wewenang yang ada. A pabila wewenang dijalankan tidak sesuai dengan dasar diberikannya wewenang, hal tersebut adalah penyalahgunaan wewenang yang secara tegas dilarang oleh undang-undang dan AUPB. Harus ada pengawasan yang bersifat eksternmaupunintern, terutamadalamhalpenyalahgunaanwewenangyangmerupakan pelayanan publik, sementara penggunaan wewenang yang tidak sesuai dengan dasar diberikannnya wewenang memiilki potensi timbulnya tindak pidana korupsi, sehingga terkait dengan pengawasan maka hukum adminisitrasi memiliki peran penting dalam upaya pemberantasan tindak pidana korupsi.

Penelitian oleh Dani Elpah dan kawan-kawan, memberi hasil bahwa terdapat empat (4) titik singgung dalam menilai penyalahgunaan wewenang oleh rezim hukum administrasi dengan hukum pidana, yaitu (i) penggunaan istilah / konsep penyalahgunaanwewenang, (2)konprehensi/konotasi/intensi(isi/ruanglingkup),(3) normadressat (alamat yang dituju oleh sebuah norma /subyek norma), (4) normgedrag (perilaku yang dikehendaki atau tidak dikehendaki) yaitu menggunakan wewenang untuk tujuan lain dari diberikannya wewenang. Keempat titik singgung di atas yang berakhir pada persinggungan kewenangan mengadili, selain itu Perma No 4 Tahun 2015 tentang Pedoman Beracara dalam Penilaian Unsur Penyalahgunaan Wewenang tidak serta merta menyelesaikan polemik kewenangan mengadili ${ }^{26}$.

Pasal 2 ayat (1) Perma No 4 Tahun 2015 menyebutkan bahwa pemohon dapat mengajukan permohonan ada atau tidaknya unsur penyalahgunaan ke Pengadilan Tata Usaha Negara sebelum ada proses pidana. Penjelasan pasal tersebut tidak menjelaskan lebih lanjut mengenai apa yang dimaksud sebelum ada proses pidana, batasan apa yang dimaksud proses pidana. Pada penelitian oleh Dani Elpah, hal tersebut juga merupakan salah satu polemik yang timbul di antara hakim Peratun maupun Hakim Tipikor yang masing- masing memiliki latar belakang pemikiran berbeda dan didukung dengan rasionalitas keilmuan yang dimiliki.

Dalam frasa " sebelum ada proses pidana" Pasal 2 ayat (1) PERMA No 4 Tahun 2015 menimbulkan pertanyaan, apabila terhadap perkara tersebut sudah diperiksa sesuai ketentuan hukum pidana, maka tidak perlu diperiksa sesuai ketentuan hukum adaministrasi, dan apakah proses penegakan hukum administrasi negara menduduki tempatkeduasetelahhukumpidana.Peraturanperundanganyangmenjadidasarhukum timbulnya Perma No 4 Tahun 2015 adalah UU AP, sementara pemeriksaan perkara tindak pidana korupsi berdasarkan UU No 31 Tahun 1999 tentang Pemberantasan Tindak Pidana Korupsi, yang menunjukkan bahwa keduanya merupakan peraturan

\footnotetext{
${ }^{25}$ Bagir Manan, 2009, "Penegakan Hukum Yang Berkeadilan," dalam Menegakkan Hukum Suatu Pencarian, Asosiasi Advokat Indonesia, Jakarta, hlm 51-61.

${ }^{26}$ Dani Elpah dkk, 2016, Titik Singgung Kewenangan Antara Pengadilan Tata Usaha Negara Dengan Pengadilan Tindak Pidana Korupsi Dalam Menilai Terjadinya Penyalahgunaan Wewenang , Pusat Penelitian dan Pengembangan Mahkamah Agung Republik Indonesia, Jakarta, hlm 67.
} 
perundangan sesuai Pasal 7 ayat (1) UU No 12 Tahun 2011 tentang Pembentukan Peraturan Perundang-undangan, jadi memiliki kedudukan yang sama sejajar. Dari hasil wawancara dengan Sutiyono, S.H., MH, ada beberapa hal penting, pertama dalam hal penyelesaian perkara yang berada di dua ranah hukum yang berbeda, seyogyanya juga diselesaikan secara bersamaan dalam arti tidak ada yang didahulukan dari yang lainnya, atau lebih bersifat superior, dan harus dipatuhi oleh warga negara. Hal penting lainnya yang dikemukakan yaitu perlu dipahami dasar filosofi Pasal 21 UU AP yaitu untuk menjembatani pergesekan antara hukum pidana dan hukum administrasi negara, serta perlu dirumuskan kembali isi Perma terkait, agar pemerintahan yang bersih dan baik dapat tercapai.

Adapun usul yang dikemukakan adalah perlu di rumuskan kembali dengan mendasarkan pada 2 pilihan, pertama, adalah pasal tersebut dihilangkan. Sehingga, pemeriksaan proses pidana dan administrasi berjalan bersama-sama. Kedua, apabila pasal tersebut dipertahankan, maka perlu ada 1 pasal lagi yang menyebutkan bahwa penyidik belum boleh melakukan penyelidikan, sebelum ada hasil pemeriksaan dari Peratun yang berupa putusan Pengadilan Tata Usaha Negara yang berkekuatan hukum tetap.

Dikemukakan oleh Yulius, bahwa dalam konteks pengujian mengenai unsur penyalahgunaan wewenang, tidak perlu diperdebatkan; karena perluasan makna penyalahgunaanwewenangsudahmenjadinorma dalamUU AP, yangharus dijalankan, karena undang-undang berdasarkan asas legalitas mengikat umum karena dibentuk oleh lembaga yang berwenang, yaitu Presiden dan DPR. ${ }^{27}$.

Dalam hal yang berkaitan antara jabatan dan pejabat administrasi negara, pertama harusdiperhatikanadalahmemeriksahubunganantarajabatanataupejabatadministrasi negaradenganhukumadministrasinegara,kedua,barudapatdilaksanakanpemeriksaan menurut hukum lain. Hal tersebut didasarkan bahwa hukum administrasi negara sebagaihukumyangmandiridanmemilikisistem, metodepelaksanaandanpenegarakan sendiri yang tidak boleh dicampur adukkan dengan hukum lain ${ }^{28}$.

Pasal 53 ayat (2) hurufb UU Peratun mengatur mengenai syarat materiil pengajuan gugatan, yang sebenarnya merupakan dasar pembatalan disebut penyalahgunaan wewenang, sedangkan untuk huruf c, dasar pembatalan sering disebutlarangan berbuat sewenang-wenang. Isi Pasal 53 ayat (2) huruf b dan c diubah sehingga menempatkan AUPB sebagai dasar untuk mengajukan gugatan dengan melihat UU No 28 Tahun 1999 tentang Penyelenggaraan Negara yang Bersih dan Bebas dari Korupsi, Kolusi dan Nepotisme, meliputi asas kepasatian hukum, tertib penyelenggaraan negara, keterbukaan, proporsionalisme, profesionalisme dan akuntabilitas.

RomliAtmasasmitamerujukpadanegaraUniEropayangmenurutOswaldJansenada 2 pandanganyang mengakuikeberadaansanksiadministrasi tidak mengenyampingkan sanksi pidana atau disebut "low degree of differentiation" dan pandangan bahwa keberadaan sanksiadministrasi harus dipisahkan tegas darisanksi pidana atau disebut " high degree of differentiation", sebaiknya diberikan hak preferensi kepada Peratun untuk memeriksa dan mengadili pejabat pemerintah, sebelum pengadilan tipikor memeriksa dan mengadili pejabat tersebut dalam kasus korupsi ${ }^{29}$.

\footnotetext{
${ }^{27}$ Enrico Simanjuntak, 2018, "Permohonan Ada Tidaknya Pengujian Penyalahgunaan Wewenang," dalam $\mathrm{Hu}$ kum Acara Peradilan Tata Usaha Negara Transformasi \& Refleksi ,Sinar Grafika, Jakarta, hlm 138-44.

${ }^{28}$ Bagir Manan, 2009, "Perlindungan Hukum Terhadap Pejabat Publik Daerah, " dalam Menegakkan Hukum Suatu Pencarian, Asosiasi Advokat Indonesia, Jakarta, hlm 305 - 321.

${ }^{29}$ Irvan Mawardi, 2016, Paradigma Baru PTUN Respon Peradilan Administrasi Terhadap Demokratisasi, Thafa Media, Yogyakarta, hlm 119 - 138.
} 
SesuaiisiPasal21UUAP, memberiperluasan kompetensiPeratun, yangsebelumnya tidak diatur dalam UU No 5 Tahun 1986 tentang Peratun. Formulasi rumusan Pasal 21 UU AP jo Pasal 1 Perma No 4 Tahun 2015 tentang Pedoman Beracara Dalam Penilaian Unsur Penyalahgunaan Wewenang, secara jelas menyebutkan bahwa permohonan diajukankePeratun.,halinimenegaskanbahwapenyelesaiansecarahukumadministrasi negara adalah yang utama. Dalam hal ada unsur penyalahgunaan wewenang yang dihubungkan dengan tindak pidana korupsi, penyelesaian melalui hukum pidana tidak lagi menjadi tujuan utama ${ }^{30}$.

Sesuai dengan sistem hukum Civil Law yang menganut "duality of jurisdiction" yaitumemisahkanjenisperadilanberdasarkankompetensiabsolut,peranyurisprudensi adalah penting sebagaimana di Perancis, Belanda. Peran Mahkamah Agung sangat penting karena hukum administrasi pada dasarnya lebih banyak bersifat hukum yurisprudensial. Hal yang berbeda dengan negara dengan sistem hukum Common Law yang menganut "unity ofjurisdiction", bahwa kompetensi mengadili tidak menjadi problematika, karena hanya ada peradilan umum dan tidak ada lingkungan peradilan lain. ${ }^{31}$. Penjelasan di atas, sesuai dengan kompetensi Peradilan Administrasi di Inggris, yang tidak meletakkan Administrative Tribunal di bawah kekuasan Mahkamah Agung atau Supreme Court.

Sebelum Perma No 4 Tahun 2015 tentang Pedoman Beracara Dalam Penilaian Unsur Penyalahgunaan Wewenang, ada putusan PTUN Medan No 25/ G/ 2015/ PTUN-MDN yang mengabulkan permohonan Pemohon dan termohon terbukti telah melakukan penyalahgunaan wewenang. Pemeriksaan dilakukan sebagaimana pemeriksaan gugatan, meskipun para pihak yang berpekara disebut sebagai Pemohon dan surat perintah penyidikan sebagai obyek permohonan.

Perkara No 250/P/PW/ 2015/PTUN-JKT ditolak oleh Majelis Hakim, karena berdasarkan keterangan saksi, pengetahuan hakim dan pengetahuan umum, bahwa pemohon sudah diputus perkaranya di Pengadilan Tipikor. Terhadap perkara No 15/P/ PW/2016/PTUN.PLK Majelis Hakim menolak permohonan, karena Pemohon tengah menjalani proses pidana yaitu tahap penyidikan dan berstatus sebagai tersangka. Dari duaputusan PTUN tersebutdi atas, menunjukkanbahwa Peratun sudah melaksanakan isi Pasal 21 UU AP dan Perma No 4 Tahun 2015, yaitu pemeriksaan permohonan dilaksanakan sesuai ketentuan perundangan, dan ketika diketahui bahwa terhadap pemohon telah menjalani pemeriksaan proses pidana, maka Pengadilan memutuskan permohonan di tolak.

Berdasarkan pertimbangan hukum Majelis Hakim dalam putusan No 09/ P/ PW/ 2018/PTUN.Srby, bahwa terbukti secara sah dan meyakinkan bahwa tidak ada unsur penyalahgunaan wewenang yang dilakukan oleh Pemohon dalam menerbitkan obyek permohonan. Hal menarik dari perkara No 2 / P / PW / 2017 / PTUN.JBI ada 2 obyek permohonanyaitu Addendum ISuratPerjanjjianatas Tambahan WaktuKontrak Untuk Melaksanakan PaketPekerjaan Konstruksi Embung Sungai Abang Kecamatan VIIKoto, Kabupaten Tebo No 521/263/SP/IV/DPT/2015 tanggal 21 Desember 2015 beserta akibat hukumnya, dan Nota Dinas No 521.21/247/IV/DPTP/2016 tanggal 16 Mei 2016 perihal permohonan pemeriksaan pembangunan Embung di Desa Sungai Abang, KecamatanVIIKoto,Kabupaten TeboTahunAnggaran2015, Majelismemutuskantidak

\footnotetext{
${ }^{30}$ Bagir Manan, 2009, "Penegakan Hukum Yang Berkeadilan", dalam Menegakkan Hukum Suatu Pencarian, Asosiasi Advokat Indonesia, Jakarta, hlm 51-61.

${ }_{31}$ Paulus Effendi Lotulung, 2013, "Peratun Di Indonesia Dibandingkan Dengan Peradilan Adminisitrasi Yang Berlaku Di Berbagai Negara," dalam Hukum Tata Usaha Negara Dan Kekuasaan, Salemba Humanika, Jakarta:, hlm $51-62$.
} 
ada penyalahgunaan wewenang dalam diskresi yang dilakukan Pemohon. Permohonan pemeriksaan terhadap diskresi yang dikeluarkan oleh Pemohon menunjukkan bahwa terhadap diskresi dapat dilakukan pengujian ada atau tidaknya unsur penyalahgunaan wewenang.

Sesuai isi Pasal 2 ayat 1 Perma No 4 Tahun 2015 yang menyebutkan kekuasaan pengadilan dan kedudukan hukum Pemohon, bahwa tidak disebutkan ada pembatasan terhadap obyek sengketa, artinya diskresi juga dapat diajukan untuk diperiksa oleh Peratun.

\section{d. Penegakan hukum di bidang hukum administrasi negara.}

Penegakan hukum bidang administrasi negara kurang mendapat perhatian, sementara hal tersebut sesungguhnya penting terutama untuk menuju tata kelola pemerintahan dan pelayanan publik yang baik. Selain itu, juga terkait dengan upaya perlindungan hukum bagi warga negara terhadap tindakan hukum pemerintah.

Dalam Sistem Peradilan Tata Usaha Negara penegakan hukum bidang administrasi negara, terdiri dari penggugat, tergugat dan hakim. Pelaku penegakan hukum bidang administrasi negara tidak hanya padalembaga pengadilan, tetapi pejabatataubadan tata usaha negara juga memiliki peran penting. Jika terjadi pelanggaran, dapat dikenakan sanksi administrasi sesuai peraturan perundangan yang berlaku,jadi pelaku penegakan hukum serta jenis sanksi yang dikenakan berbeda.

Menurut Bagir Manan, ada 3 (tiga) syarat yang harus dipenuhi untuk penegakan hukum, yaitu pertama, hukum yang akan ditegakkan dan hukum yang mengatur mengenai cara-cara penegakan hukum adalah benar dan adil. Kedua, pelaku penegakan hukumsebagaihalutamadalampenegakanhukumyangberkeadilan. Ketiga, lingkungan sosial tempat hukum berlaku ${ }^{32}$.

Pelaksanaan putusan Pengadilan yang telah berkekuatan hukum tetap merupakan masalah penting dalam Sistem Peradilan Tata Usaha Negara, terutama dalam hal penegakan hukum. Hal ini berawal dari putusan Pengadilan yang menyebutkan bahwa gugatan dikabulkan dan dapat ditetapkan kewajiban yang harus dilakukan oleh Badan atau Pejabat Tata Usaha Negara yang mengeluarkan keputusan Tata Usaha Negara.

Pengaturan pelaksanaan putusan Pengadilan yang telah memperoleh kekuatan hukum tetap, dalam UU Peratun Pasal 116 jo UU No 9 Tahun 2004 jo UU No 51 Tahun 2009 tentang Perubahan Kedua Atas UU No 5 Tahun 1986 tentang Peratun. Hal ini adalah upaya Pemerintah dari sisi hukum yang mengatur cara penegakan hukum yang adil dan benar.

Tergugat sebagai pihak yang diberi kewajiban untuk melaksanakan putusan Pengadilan seringkali tidak melaksanakan putusan yang menjadi kewajibannya. Keengganantergugatuntukmelaksanakanputusanpengadilandapatdisebabkankarena kurangnya kepatuhan hukum (legal obedience) terhadap putusan Pengadilan, hal ini juga berkaitan erat dengan budaya hukum yang melekat pada setiap orang.

Pasal 116 UU NO 5 Tahun 1986 tentang Peratun mengatur mengenai pelaksanaan putusan pengadilan yang telah memperoleh kekuatan hukum tetap secara berjenjang, yang dimulai dari permohonan oleh Penggugat kepada Pengadilan agar memerintahkan kepada Tergugatuntuk melaksankan isi putusan, dalam haladakewajibanbagi Tergugat sesuaiPasal97ayat(9)hurufbdanc. Apabilatidakdilaksanakan,Pengadilanmengajukan hal tersebut kepada instansi atasan Tergugat menurut jenjang jabatan. Jika tetap tidak

${ }^{32}$ Indriati Amarini, 2018, Keaktifan Hakim Dan Peradilan Administrasi, 2nd ed, UM Purwokerto Press, Purwokerto, hlm. 13. 
melaksanakan, Pengadilan mengajukan hal tersebutkepada Presiden sebagaipemegang kekuasaan tertinggi agar memerintahkan Tergugat melaksanakan putusan pengadilan. Pengajuan sesuai dengan instansi menurut jenjang jabatan, belum dapat mewujudkan penegakan hukum bidang administrasi negara.

Amandemen Pasal 116 dalam UU No 9 Tahun 2004 tentang Perubahan Atas UU No 5 Tahun 1986 tentang Peratun, merubah formulasi mekanisme pelaksanaan putusan, yaitu dapat dilakukan upaya paksa berupa pembayaran sejumlah uang paksa dan/ atau sanksi administratif, pengumuman di media cetak setempat. Perubahan ini tidak didukung oleh peraturan perundangan sebagai pelaksana yang mengatur mekanisme pembayaran uang paksa dan/atau uang paksa. Pengumuman di media cetak setempat pun, juga belum dapat membantu penegakan hukum.

Perubahan kedua Pasal 116 dalam UU No 51 Tahun 2009 tentang Perubahan Kedua Atas UU No 5 Tahun 1986 tentang Peratun, masih tetap mencantumkan pembayaran uang paksa dan/atau sanksi administratif, pengumuman di media cetak, menambahkanbahwajikatergugattidakmelaksanakanputusanPengadilan, makaKetua Pengadilan harus mengajukan hal tersebut kepada Presiden untuk memerintahkan kepadaTergugatdanmelaporkankepadalembagaperwakilanrakyatuntukpengawasan. Secara substansi hukum, Pemerintah berupaya agar pelaksanaan putusan Pengadilan yang telah memperoleh kekuatan hukum tetap dapat dilaksanakan, agar dapat memberi kepastian hukum, keadilan dan kemanfaatan.

Kewajiban tergugat untuk membayar ganti rugi atau kompensasi kepada penggugat, dapat menggunakan pendapatKranenburg dan Vegting mengenai pertanggungjawaban pemerintah yaitu pertama, fautes personalles yang menyatakan bahwa kerugian dibebankan kepada pejabat, kedua, fautes de services yaitu kerugian dibebankan kepada instansi dari pejabat yang bersangkutan. Pendapat senada dikemukakan oleh Supandi secara teori bahwa seseorang yang melaksanakan tugas negara dan pada saat menjalankan tugasnya mengakibatkan kerugian bagi orang atau warga negara, maka kerugian yang timbul, pembayarannya dibebankan kepada Negara ${ }^{33}$. Pengaturan pelaksanaan ganti rugi dan kompensasi diatur di Peraturan Pemerintah No 43 Tahun 1991 tentang Ganti Rugi dan Tata Cara Pelaksanaannya Pada Peradilan Tata Usaha Negara, namun demikian sesuai dengan perkembangan pemerintahan, hukum dan perekonomian, perlu kiranya untuk disusun kembali pengaturan pembayaran ganti rugi, kompensasi serta mekanisame yang lebih jelas.

Mengenai penerapan uang paksa, menurut Ismail Rumadan adalah tidak tepat. Alasan yang menjadi dasar yaitu harapan penggugat adalah adanya perubahan atas keputusan TUN yang digugat, baik dicabut atau diterbitkan keputusan TUN baru, dan uang paksa yang dibebankan sebagai ganti rugi tidak bisa mengompensasi kerugian yang diderita penggugat ${ }^{34}$.

UU AP tidak mengatur mengenai jenis serta mekanisme upaya paksa yang dapat dikenakan kepada Pejabat Tata Usaha Negara yang tidak melaksanakan putusan Pengadilan yang telah memperoleh kekuatan hukum tetap. Di satu sisi, UU AP jelas bertujuan untuk meningkatkan kualitas pelayanan pemerintah kepada masyarakat, namun penegakan hukum terhadap pelaksanaan putusan pengadilan nampaknya

\footnotetext{
${ }^{33}$ Umar Dani, 2015, Putusan Pengadilan Non-Executable Proses Dan Dinamika Dalam Konteks PTUN, Genta Publishing, Yogyakarta,hlm 50.

${ }^{34}$ Ismail Rumadan, "Problematika Eksekusi Putusan Pengadilan Tata Usaha Negara," http://www.jurnalhukumdanperadilan.org/index.php/jurnalhukumperadilan/article/view/52/63 Jurnal Hukum Dan Peradilan 1, no. 3 (2012): 435-62. Diakses pada tanggal 23 Desember 2018
} 
belum didukung oleh peraturan perundangan yang berorientasi kepada pemenuhan rasa keadilan bagi penggugat.

Tidak dilaksanakannya putusan Pengadilan yangberkekuatan hukum tetap, adalah salah satu bentuk penegakan hukum yang belum dapat memberi keadilan bagi pihak yang menang dalam sengketa. Dalam negara hukum, Peratun harus mewujudkan esensi penegakan hukum yaitu keadilan sosial bagi rakyat sebagai subyek dalam negara hukum ${ }^{35}$.

Penegakanhukumyangadildanberkeadilan, menurutBagirManan,ada2(dua)aspek penting terkaithal tersebutyaitu cara penegakanhukum (proceduraljustice) danisiatau hasil penegakan hukum (substantivejustice) ${ }^{36}$. Fungsi Peratun melakukan pengawasan serta peradilan memiliki peran penting untuk dapat tercapainya keadilan substantif, melalui putusan Pengadilan yang mengandung nilai keadilan dan kemanfaatan. Hasil penegakan hukum yaitu dengan dilaksanakannya putusan Pengadilan, sehingga dapat mewujudkan keadilan, kepastian hukum serta kemanfaatan.

KeadilanadministrasiatauadministrationjusticeperludikembangkandiIndonesia, terutama dengan adanya penilaian ada atau tidaknya unsurpenyalahgunaanwewenang dengan menempatkan sesuai ranah hukum adminisitrasi negara.

Sistem Peratun terkait dengan keadilan administrasi, yang menurut Galligan ada 2 (dua) perspektif, yaitu pertama, government yang di dalamnya terdiri dari berbagai hal mulai dari ketepatan waktu, kemampuan manajerial untuk menghasilkan keputusan yang baik, manajemen organisasi pemerintahan, dan kedua, legal yaitu mengenai keadilan, bahwa kedua perspektif tersebut memiliki kelebihan dan kekurangan untuk mencapai keadilan adminisitrasi ${ }^{37}$.

Menurut Martin Partington, “....the administrativejustice is a concept that admitedly difficult to define and embraced the whole-range of decision taking from first decision to final appeal not simply those processes that can be labelled adjudicative". Pendapat lain dikemukakan oleh Peter Caine bahwa "... administrative justice in some respects narrower than administrative law, because of its focus on the making of decisions about individual...". Gordon Anthony dalam jurnalnya menyebutkan "... that administrative justice may be described as the overall system by which decisions of an administrative or executive nature are made in relation to particular persons including (a) the procedure in making such decisions, (b) the law under which such decisions are made and (c) the system for resolving disputes and airing grievances in relations to such decisions" ${ }^{38}$.

Meskipun sudah ada peraturan yang tepat dan memadai, standart operasional, lembaga pengadilan, lembaga pemerintahan hal tersebut belum cukup, karena harus didukung oleh budaya, sikap yang berorientasi kepada keadilan administirasi ${ }^{39}$.

\footnotetext{
35 Willy Riawan Tjandra, 2017, "Dinamika Keadilan Dan Kepastian Hukum Dalam Peradilan Tata Usaha Negara," Mimbar Hukum, no. Edisi khusus, hlm 75-88, http://download.portalgaruda.org/article.php?article $=281481 \& v a l=7175 \&$ title $=$ Dinamika Keadilan dan Kepastian Hukum dalam Peradilan Tata Usaha Negara. Diakses pada tanggal 10 Desember 2018.

${ }^{36}$ Bagir Manan, 2009, "Penegakan Hukum Yang Berkeadilan." dalam Menegakkan Hukum Suatu Pencarian, Asosiasi Advokat Indonesia, Jakarta, hlm 51-61.

${ }^{37}$ Robert Thomas and Joe Tomlinson, 2017, "Mapping Current Issues in Administrative Justice: Austerity and the 'More Bureaucratic Rationality' Approach," Journal of Social Welfare and Family Law 39, no. 3, hlm 380-99, https://doi.org/10.1080/09649069.2017.1363526.diakses pada tanggal 2 Desember 2018.

${ }^{38}$ Gordon Anthony, 2015, “Administrative Justice in the United Kingdom," https://www.ijpl.eu, Italian Journal of Public Law, Vol 7, no. 1, hlm : 9-33., diakses pada tanggal 20 November 2018.

${ }^{39}$ R Creyke, 2007, "Administrative Justice - Towards Integrity in Government," https:// www.law.unimelb.edu.au/mulr. Melbourne University Law Review 31, no. 3 ,hlm 705-32.how it is used, and examines which bodies should be subject to administrative justice. The most vexed issue, however is how to assess whether administrative justice has been achieved. By what standard is administrative justice to be measured? The author has chosen a methodology based on that adopted by Australian researchers who mapped national integrity systems. Since administrative law bodies were among the government agencies selected for that research, the hypothesis is that a methodology which applies
} 
Keadilan administrasi atau administration justice merupakan konsep baru, yang masih dalam tahap pengembangan dan belum ada suatu konsep atau definisi yang pasti mengenai arti keadilan administrasi. Namun demikian, ada beberapa hal penting yang dapat digunakan untuk mengetahui hal-hal apa saja yang perlu diperhatkan agar keadilan administrasi dapat dicapai.

Berbagai pendapat mengenai standar untuk dapat mencapai keadilan administrasi dikemukakan, antara lain D.J. Galligan "...by upholding the standards of fair treatment in the statutory scheme, together with standards deriving from other sources...". Fred J “... administrative justice standards of lawfulness, fairness, rationality and intelligibility from what he described as the basic and well-established ground of judicial review". ${ }^{40}$.

Standar keadilan administrasi yang bersifat umum, antara lain akuntabilitas, transparansi, penegakan hukum administrasi, rasionalitas, kejelasan pada tahap pengambilan keputusan, dan lain-lain yang dapat ditemukan pada penyelenggaraan pemerintahan.

Secara universal ada kesamaan dalam standar keadilan administrasi dengan AUPB , yaitu asas keterbukaan, asas ketidakberpihakan, asas pelayanan yang baik, asas kecermatan, namun demikian tetap pula sesuai dengan asas lain dalam AUPB. Penegakan hukum administrasi negara, tidak hanya mencakup pelaksanaan putusan Pengadilan yang telah memperoleh kekuatan hukum tetap, tetapi juga terpenuhinya standarkeadilan administrasiyangsesuai dengan peraturan perundanganyangberlaku.

Penyelenggaraan pemerintahan yang sesuai dengan peraturan perundangan dan AUPB, adalah gambaran pemerintahan yang ideal. Agar pemerintahan yang ideal ini dapat tercapai, berbagai norma hukum administrasi harus ditegakkan, selain juga norma hukum lain yang bersesuaian, misalkan norma kepatuhan hukum.

Norma kepatuhan hukum bagi pejabat dan atau badan pemerintahan diartikan sebagai kepatuhan menyelenggarakan pemerintahan, termasuk pula kepatuhan menjalankan putusan pengadilan yang berkekuatan hukum tetap. Norma kepatuhan hukum melekat pada setiap orang, danberkaitan dengan moralitas hukum yang penting dalam negara hukum, karena juga terkait dengan hak dan kewajiban sebagai warga negara.

Bahwasanya, ketaatan hukum (legal obedience) setiap orang juga terkait dengan moralitas hukum yang ada dan budaya hukum untuk mematuhi peraturan yang ada, agar tercipta ketertiban dan keadilan. Dalam hal ketaatan hukum dari tergugat untuk melaksanakan putusan pengadilan yang telah memperoleh kekuatan hukum tetap,juga diikuti dengan self respect, hal ini sebagai faktor utama dan pembeda, dibandingkan dengan penegakan hukum dibidang lain. Selfrespectyang baik ada pada tingkatketaatan hukum yang baik pula, sebagai wujud dari moralitas hukum dan budaya hukum.

to the whole can apply equally to the parts. That methodology was used to map the strengths and weaknesses of the administrative law system, and how coherently the system operates. The results showed that the coherence of parts of the system is questionable and that there are weaknesses in the system, but at the margins, not its core. Overall, the system was providing the outcomes for which it was established. The upshot is that although the definition of administrative justice remains elusive, a start has been made. The tools to undertake the task have been identified and it is now for administrative law institutions and others in the administrative law community to build on these steps so that this concept - integral to the administrative law system - can be better understood.","author":[\{ "dropping-particle":"',,"family":"Creyke",,"given":"R","non-dropping-particle":"”,"parse-names":false,"suffix":"”'\}],"container-title":"Melbourne University Law Review","id":"ITEM-1","issue":"3","issued":\{“date-parts":[["2007"]]\}, "page":"705-732","title":"Administrative justice - Towards integrity in government","type":"article-journal","volume":"31"\},"uris":[“http://www.mendeley.com/documents/?uuid = d9ea89f8-e1bc-4fe9-8fca-658a5246935e"]\}]," mendeley": “"formattedCitation":"R Creyke, "Administrative Justice - Towards Integrity in Government," < i > Melbourne University Law Review </i > 31, no. 3 (2007diakses pada tanggal 28 November 2018.

${ }^{40}$ Robin Creyke, 1999, "Administrative Justice-The Core and the Fringe,", https://www.aial.org.au. Diakses pada tanggal 28 November 2018. 
Bertitik tolak dari perspektif yang dikemukakan Galligan di atas, pemerintah sebagai pemegang kekuasaan tertinggi memiliki peran penting untuk tercapainya keadilan administrasi. Pertama, melalui peraturan perundangan yang disusun bersama legislatif yang secara jelas menjamin kedudukan yang sama bagi warga negara di bidang hukum dan pemerintahan. Hal ini merupakan salah satu prinsip penting dalam negara hukum. Kedua, bahwa kedudukan yang sama di bidang hukum dan pemerintahan sebagai wujud keadilan. Warga negara memiliki hak yang sama untuk mendapatkan keadilan, pelayanan publik yang baik, yang pada intinya adalah terpenuhinya hak-hak sipil warga negara.

Pelaksanaan putusan pengadilan selain merupakan penegakan hukum yang diharapkan dapat memberi keadilan adminisitrasi, juga dapat berarti akuntabilitas hukum sebagai bentuk pertanggungjawaban publik dari pemerintah kepada warga negara. Akuntabilitas hukum yang merupakan bagian dari akuntabilitas publik, sebagaimana dikemukakan oleh Brautigam, disamping akuntabilitas ekonomi, akuntabilitas politik. Adapun hakikat dari akuntabilitas hukum adalah pertanggungjawaban dari segi hukum terhadap tindakan pemerintah yang dapat dipertanggunjawabkan kepada lembaga legislatif, lembaga yudikatif ${ }^{41}$.

PertanggungjawabantindakanpemerintahselaindipertanggunjawabkandiPeratun atau di peradilan umum, juga harus dipertanggungjawabkan kepada warga negara yang dirugikan akibat tindakan hukum pemerintah. Selain itu, pertanggungjawaban pemerintah merupakan salah satu bentuk pelaksanaan AUPB untuk tercapainya tata kelola pemerintahan yang baik, yaitu asas kepastian hukum, asas pelayanan yang baik, asas kepentingan umum.

Setiap penyelenggaraan pemerintahan terkait dengan bentuk pelayanan publik dan pertanggungjawaban publik terhadap pemenuhan hak-hak sipil warga negara. Pertanggungjawabanpublikiniyangharusdapatdiwujudkandalambentukpelaksanaan putusan pengadilan, karena untuk memenuhi atau mengembalikan penggugat kembali pada kondisi semula, tidak dapat terpenuhi secara sepenuhnya.

Dalam kerangka penegakan hukum administrasi yang mencakup pula keadilan administrasi, perlu dipahami bahwa tercapainya hal tersebut sebagai tujuan negara berdasarkan Pancasila dan UUD 1945.

\section{SIMPULAN}

Secara tegas Pasal 21 UU AP sudah menyebutkan kompetensi Peratun untuk memeriksa unsur penyalahgunaan wewenang, sehingga seyogyanya tidak ada lagi polemik mengenai kompetensi mengadili. Dari sisi hukum administrasi, wewenang sepenuhnya berada di ranah hukum administrasi negara, sehingga kompetensi untuk melakukan pengujian terhadap keputusan dan/atau tindakan pejabat atau Badan Pemerintah pengujian serta kewenangan menjadi kompetensi Peratun.

Ketidaktaatan untuk melaksanakan putusan Peratun yang telah memperoleh kekuatan hukum selain menghambat penegakan hukum administrasi, dengan sendirinya juga tidak mewujudkan keadilan administrasi bagi pihak yang menang. Timbulnya penyalahgunaan wewenang, ketidaktaatan untuk melaksanakan putusan Peratun yang telah memperoleh kekuatan hukum tetap, sebagai salah satu bentuk ketidaktaatan

${ }^{41}$ Paulus Effendi Lotulung, 2013, "Tata Kepemerintahan Yang Baik (Good Governance) Dalam Korelasinya Dengan Hukum Administrasi," dalam Hukum Tata Usaha Negara Dan Kekuasaan, Salemba Humanika, Jakarta, hlm 141150. 
hukum (disobedience, non-complianace of law) yang dilakukan oleh pejabat tata usaha negara.

\section{DAFTAR PUSTAKA}

\section{Buku}

Abdoellah, P, (2016), Revitalisasi Kewenangan PTUN Gagasan Perluasan Kompetensi Peradilan Tata Usaha Negara, Cahaya Atma Pustaka, Yogyakarta.

Abdullah, A, (2017), Teori dan Praktik Hukum Acara Peradilan Tata Usaha Negara, Jala Kencana, Jakarta.

Dani, U. (2015), Putusan Pengadilan Non-Executable Proses dan Dinamika dalam Konteks PTUN. Yogyakarta: Genta Publishing.

Disiplin F.Manao, (2017), Penyalahgunaan Wewenang Pada Tindak Pidana Korupsi Dalam Perspektif Hukum Administrasi Negara,Kreasi Sahabat Bersama, Bandung.

Enrico Simanjuntak, (2018), Permohonan Ada Tidaknya Pengujian Penyalahgunaan Wewenang, Tarmizi (Ed), Hukum Acara Peradilan Tata Usaha Negara Transformasi \& Refleksi, Sinar Grafika, Jakarta.

Indriati Amarini, (2018), Keaktifan Hakim dan Peradilan Administrasi (2nd ed.). UM Purwokerto Press, Purwokerto.

Indroharto, (2000), Usaha Memahami Undang-undang Tentang Peradilan Tata Usaha Negara Buku I Beberapa Pengertian Dasar Hukum Tata Usaha Negara, Pustaka Sinar Harapan, Jakarta.

Ishaq, (2016), Penelitian Hukum Dengan Menggunakan Metode Penelitian Sosial, Metode Penelitian Hukum Dan Penulisan Skripsi, Tesis Serta Disertasi, Alfabeta, Bandung.

Manan, B., (2009), Penegakan Hukum Yang Berkeadilan, Menegakkan Hukum Suatu Pencarian, Asosiasi Advokat Indonesia, Jakarta.

Manan, B. (2009), Perlindungan Hukum Terhadap Pejabat Publik Daerah, Menegakkan Hukum Suatu Pencarian, Asosiasi Advokat Indonesia, Jakarta.

Mawardi, I, (2016), Paradigma Baru PTUN Respon Peradilan Administrasi Terhadap Demokratisasi, Thafa Media. Yogyakarta.

Nomensen Sinamo, (2016), Kompetensi Peradilan Tata Usaha Negara. In Hukum Acara Peradilan Tata Usaha Negara, Jala Permata Aksara, Jakarta.

Philipus M. Hadjon, dkk, (2011), Hukum Administrasi Dan Tindak Pidana Korupsi., Gadjah Mada University Press, Yogyakarta.

Philipus M. Hadjon, dkk, (2011), Maladministrasi dan Peran Pengawasan Dalam Pelayanan Publik. In Hukum Administrasi Dan Tindak Pidana Korupsi, Gadjah Mada University Press, Yogyakarta.

Paulus Effendi Lotulung, (2013), Peratun Dalam Kaitannya Dengan Rechtsstaat Republik Indonesia, Tim Editor Salemba Empat (Ed), Hukum Tata Usaha Negara dan Kekuasaan, Salemba Humanika, Jakarta.

Paulus Effendi Lotulung, (2013), Peratun di Indonesia Dibandingkan dengan Peradilan 
Adminisitrasi yang Berlaku di Berbagai Negara, Tim Editor Salemba Empat (Ed), Hukum Tata Usaha Negara dan Kekuasaan, Salemba Humanika, Jakarta.

Paulus Effendi Lotulung, (2013), Tata Kepemerintahan yang Baik (Good Governance) Dalam Korelasinya dengan Hukum Administrasi, Tim Editor Salemba Empat ( Ed), Hukum Tata Usaha Negara dan Kekuasaan, Salemba Humanika, Jakarta.

Ridwan, (2003). Kedudukan, Kewenanga, dan Tindakan Hukum Pemerintah, Hukum Administrasi Negara, UII Press, Yogyakarta.

Ridwan, (2009), Tiga Dimensi Hukum Administrasi dan Peradilan Administrasi, FH UII Press, Yogyakarta.

Ridwan, (2016), Persinggungan Antar Bidang Hukum Dalam Perkara Korupsi, FH UII Press, Yogyakarta.

\section{Journal dan karya ilimiah lain}

Anthony, Gordon. (2015). "Administrative Justice in the United Kingdom." https:// www.ijpl.eu Italian Journal of Public Law, Vol .7, no. 1: 9-33.

Asimow, Michael. (2018). "Five Models OfAdministrative Adjudication.", https:// academic.oup.com/ajcl, The American Journal of Comparative Law 63, no. July: $3-32$.

BUUÇAM, Ziya Bekir. "Common Principles of Judicial Review of Administration in Europe: A Comparative Study of France, The UK, The ECHR and the EU." Law \& Justice Review, no. 5 (2012). http://www.taa.gov.tr/indir/commonprinciples-of-judicial-review-of-administration-in-europe-a-comparative-studyof-france-the-uk-the-echr-and-the-eu-bWFrYWxlfDBkYTlmLWUwNmQ4LTg2NGM5LTUwOTE5LnBkZnw1NTg/.

Creyke, R. (2007). “Administrative Justice - Towards Integrity in Government.” https:// www.law.unimelb.edu.au/mulr., Melbourne University Law Review 31, no. 3 70532.

Creyke, Robin. (1999)."Administrative Justice-The Core and the Fringe,” , https:// www.aial.org.au.

Disiplin F.Manao, (2018). "Penyelesaian Penyalahgunaan Wewenang Oleh Aparatur Pemerintah Dari Segi Hukum Administrasi Dihubungkan Dengan Tindak Pidana Korupsi." http ://ejournal.sthb.ac.id/index.php/jwy, Wawasan Yuridika.

Firna Novi Anggoro. (2016). "Pengujian Unsur Penyalahgunaan Wewenang Terhadap Keputusan Dan/Atau Tindakan Pejabat Pemerintahan Oleh PTUN." http:// jurnal.fh.unila.ac.id/index.php/fiat Fiat Justisia 10, no. 4: 629-52.

Gosalbo-bono, Ricardo. (2010). "The Significance of the Rule of Law and It's Implications For The European Union And The United States." https://awreview.law.pitt. edu/ University of Pittsburgh Law Review 72, no. 2: 229-360.

Ismail Rumadan. (2012). "Problematika Eksekusi Putusan Pengadilan Tata Usaha Negara.", http://www.jurnalhukumdanperadilan.org/index.php/ jurnalhukumperadilan. Jurnal Hukum Dan Peradilan 1, no. 3: 435-62.

Maftuh Effendi. (2014). "Peradilan Tata Usaha Negara Indonesia Suatu Pemikiran Ke Arah Perluasan Kompetensi Pasca Amandemen Kedua Undang-Undang 
Peradilan Tata Usaha Negara." http://www.jurnalhukumdanperadilan.org/index. php/jurnalhukumperadilan. Jurnal Hukum Dan Peradilan 3, no. 1: 25-35.

Mohammad Sahlan. (2016). "Kewenangan Peradilan Tipikor Pasca Berlakunya UU No 30 Tahun 2014 Tentang Administrasi Pemerintahan, https://arenahukum.ub.ac. id ,Arena Hukum 9, no. 2 166-69.

Philipus M. Hadjon. (2015). "Peradilan Tata Usaha Negara Dalam Konteks UU No 30 Tahun 2014 Tentang Adminisitrasi Pemerintahan." http://www. jurnalhukumdanperadilan.org/index.php/jurnalhukumperadilan., Jurnal Hukum Dan Peradilan 4, no. 1: 51-63.

Riawan Tjandra, Willy. (2011). "Dinamika Keadilan Dan Kepastian Hukum Dalam Peradilan Tata Usaha Negara." Mimbar Hukum 0, no. Edisi khusus: 75-88. http://download.portalgaruda.org/article.php?article $=281481 \& v a l=7175 \& t$ itle = Dinamika Keadilan dan Kepastian Hukum dalam Peradilan Tata Usaha Negara.

Suhariyanto, Budi. (2018). "Penyalahgunaan Diskresi Antara Pengadilan TUN dan Pengadilan Tipikor (Interception Of Justice Authority Of Discretion Abuse Between Administration Court And Corruption Courts). " http:// www.jurnalhukumdanperadilan.org/index.php/jurnalhukumperadilan. Jurnal Hukum Dan Peradilan 7, no. 2: 213-36.

Thomas, Robert, and Joe Tomlinson. (2017). "Mapping Current Issues in Administrative Justice: Austerity and the 'More Bureaucratic Rationality' Approach." Journal of Social Welfare and Family Law 39, no. 3: 380-99. https://doi.org/10.1080/096 49069.2017.1363526.

Tri Cahya Indra Permana. (2015). "Peradilan Tata Usaha Negara Pasca UndangUndang Administrasi Pemerintahan Ditinjau Dari Segi Access To Justice ( The Administrative Court After Government Administration Acts In Terms of Access To Justice)." http://www.jurnalhukumdanperadilan.org/index.php/ jurnalhukumperadilan. Jurnal Hukum Dan Peradilan 4, no. 3: 419-42.

\section{Laporan Penelitian}

Dani Elpah, D., 2016, Titik Singgung Kewenangan Antara Pengadilan Tata Usaha Negara dengan Pengadilan Tindak Pidana Korupsi Dalam Menilai Terjadinya Penyalahgunaan Wewenang. Jakarta : Pusat Penelitian dan Pengembangan Teknis Mahkamah Agung Republik Indonesia.

Peraturan Perudang-undangan.

Undang-undang Nomor 48 Tahun 2009 tentang Kekuasaan Kehakiman ( Lembaran

Negara Tahun 2009 No 157 Tambahan Lembaran Negara No 5076)

Undang-undang Nomor 5 Tahun 1986 tentang Peradilan Tata Usaha Negara (Lembaran Negara Tahun 1986 No 77 Tambahan Lembaran Negara Nomer 3344)

Undang-undang Nomor 9 Tahun 2004 tentang Perubahan Atas Undang-undang Nomor 5 Tahun 1986 tentang Peradilan Tata Usaha Negara (Lembaran Negara Tahun 2004 No 35 Tambahan Lembaran Negara Nomer 4380)

Undang-undang Nomor 51 Tahun 2009 tentang Perubahan Kedua Atas Undang-undang Nomor 5 Tahun 1986 tentang Peradilan Tata Usaha Negara (Lembaran Negara 
Tahun 2009 No 160 Tambahan Lembaran Negara Nomer 5079)

Undang-undang Nomor 30 Tahun 2014 tentang Administrasi Pemerintahan (Lembaran Negara Tahun 2014 No 292 Tambahan Lembaran Negara Nomer 5601)

Undang-undang Nomor 31 Tahun 1999 tentang Pemberantasan Tindak Pidana Korupsi (Lembaran Negara Tahun 1999 No 140 Tambahan Lembaran Negara Nomer 387)

Undang-undang Nomor 20 Tahun 2001 tentang Perubahan Atas Undang-undang Nomor 30 Tahun 1999 tentang Pemberantasan Tindak Pidana Korupsi (Lembaran Negara Tahun 2001 No 134 Tambahan Lembaran Negara Nomer 4150)

Peraturan Pemerintah Nomor 43 Tahun 1991 tentang Ganti Rugi dan Tata Cara Pelaksanaannya pada Peradilan Tata Usaha Negara (Lembaran Negara Tahun 1991 No 52 Tambahan Lembaran Negara Nomer 3448)

Peraturan Mahkamah Agung Republik Indonesia Nomor 4 Tahun 2015 tentang Pedoman Beracara Dalam Penilaian Unsur Penyalahgunaan Wewenang 